\title{
Aspects of Movement and Mobility in Lombard Law: Fugitives, Runaway Slaves and Strangers
}

\author{
Christopher Heath*
}

Lombard laws were issued between 643 and 755. They comprise in toto an invaluable normative source for the Lombard kingdom and society in the seventh and eighth centuries. Commentators have concentrated upon the witness that the laws comprise for the ability of Lombard kings to rule, control and influence society. This paper, however, will consider aspects of both movement and mobility through and across the kingdom using the prism provided by the law with regard to fugitives, runaway slaves and strangers. What does the law tell us about the conceptual parameters associated with those who composed and compiled Lombard law? How did the Lombard kingdom respond to movement and mobility? What do prescriptions which relate to frontiers reveal about the broader interconnectivity of the Mediterranean world? In addressing these issues, and in considering the broader connotations revealed, this paper will argue for a deeper mobility in the early medieval West.

Keywords: Lombard laws; mobility; fugitives; slaves; spatial responses; Pirenne thesis; Rothari.

\section{Introduction}

At first glance, one may identify an apparent paradox with Early Medieval society in the West. On the one hand, there is a set of societies forged by the movement of peoples and ruling elites into parts of the former Western Roman Empire, but on the other hand, such societies were apparently organised on the basis of a social conservatism that emphasised the absence of social mobility and movement. ${ }^{1}$ In his classic work, The Birth of the Western Economy, Robert Latouche (1881-1973) observed that "any attempt « to identify the origins of economic life in the Early Middle Ages "must inevitably...raise the problem of the transition from the ancient world to the Middle Ages which contemporary German historians... like to call Kontinuität «. ${ }^{2}$ Finding a measured interpretative balance between continuities and discontinuities

* Correspondence details: Christopher Heath: Manchester Metropolitan University, Department of History, Politics and Philosophy, All Saints, Manchester, Lancashire M15 6BH; email c.heath@mmu.ac.uk.

1 Peters, Foreword, xvii. The literature on the development of early medieval Europe in terms of the movement of peoples is considerable, but one may usefully consult: Halsall, Barbarian invasions and Leyerle, Mobility and the traces of Empire.

2 Latouche, Western Economy, xiii. Latouche is not explicit as to who he means, providing no footnote. His bibliography suggests that he might have been thinking of (for instance) L. M. Hartmann's Zur Wirschaftsgeschichte Italiens in fruhen Mittelalter (Gotha, 1904) or A. Dopsch, Wirtschaftliche und soziale Grundlagen der Europäischen Kulturgeschichte (Vienna, 1923-1940) to name but two works, although, the latter was, of course, Austrian. For Alfons Dopsch, see Wood, Modern Origins, 236-241. 
across the varied landscapes of the Mediterranean basin and further afield into the Atlantic worlds of Francia, Britain and Scandinavia remains a series of challenges that continue to engage historians. ${ }^{3}$ If one were to narrow the focus and consider the Lombard kingdom on a geopolitical level, a paradoxical impression, similar to that sketched out above, is also furnished. One could characterise Lombard society of the seventh and eighth centuries as a static, self-contained entity that remained, up to the $680 \mathrm{~s}$, in a state of intermittent conflict with Byzantine-controlled territories (mainly) to the south and in an often inferior and contested relationship with the Frankish kingdoms to the north. ${ }^{4}$ At the same time, however, the spatial theatre in which the Lombard kingdom operated between the period of Rothari (636651) and Liutprand (712-744) was noticeably fluid. ${ }^{5}$ An ongoing and erratic accumulation of territory shifts the boundaries between the Lombards, on the one hand, and Byzantium, on the other, so that (ultimately) a tilting point in terms of power is reached in favour of the Lombard kingdom during the rule of Liutprand. This shift in power in the Italian peninsula reaches a symbolic crescendo with the capture of Ravenna in 751 by Aistulf (749-756). At this juncture we see the restriction of an indirect political presence of Constantinople in north-central Italy to Venice and Istria alone. ${ }^{6}$

If the spatial parameters of the kingdom throughout this period are fluid, one might think that this would be reflected in the normative source materials that we possess, such as the law. The variable frameworks within which the Lombard regnum operated, as we shall see, had an often implicit (and occasionally explicit) impact on specific prescriptions in the laws. One may detect how those who framed the titles responded to movement and mobility through, into and across the kingdom. Using the law and legal codes as evidence for impulses and responses, however, is not without implications. As Tom Lambert notes in his analysis of Anglo-Saxon law, we must be alive to the fact that law may not be a "perfect source for the reconstruction of behaviour «. ${ }^{7}$ Lambert and other commentators, when considering the

3 The literature on these issues is naturally enormous, but for entry into the issues, see McCormick, European Economy; Wickham, Framing; Loseby, Mediterranean economy.

4 For a short summary of Lombard military endeavours, see Peters, Foreword, ix-xi. For further discussion of law and contingent political rhythms, see Delogu, Editto di Rotari. See Fabbro, Warfare and the Making, for one reading of the first century of Lombard warfare in Italy. For the south, see now Zornetta, Italia meridionale longobarda.

5 After the resumption of active hostilities with Byzantium, the Lombard kingdom progressively "nibbles « away at the Byzantine controlled territory of Emilia; conquers Liguria in the 640s; and later adds Corsica and the whole of the exarchate and the pentapolis. Similar attrition occurs to the south with the enlargement of Lombard Tuscia. There was also somewhat limited expansion of Benevento at the expense of the Byzantine empire across the course of the eighth century. See Cosentino, Storia dell'Italia Bizantina, 238-245.

6 Evidence for the "peace of 680 is limited to a vague reference in Theophanes, and is thus rather unsatisfactory. See now Brown, 680 261-272. The reference in Theophanes to the "peace« may be found in Mango and Scott, Chronicle of Theophanes Confessor, 496 sub anno 6169 i.e. 677-678: For Venetia and Istria, see Gelichi and Gasparri, Venice and its Neighbours. Also pertinent is West-Harling, Three Empires. Boundaries between the Franks, the Avars and the Bavarians and the Lombards are relatively stable in the eighth century, notwithstanding Paul the Deacon's report that Liutprand had captured significant territory from the Bavarians.

7 Lambert, Law and Order, 1 and 7-8. Avoiding the projection of "alien « conceptual frameworks when tackling early medieval law is an important part of any analysis of law at this time. For Lombard law, in particular for the Edictum Rothari, the thin evidence for the application of provisions at the initial promulgation is also a difficulty. 
witness of law as a source for early medieval societies, have emphasised the methodological risks associated with accepting the texts at face value and as a straightforward window on early medieval societies. ${ }^{8}$ Notwithstanding the real variances that may disconnect the initial aims of those who drafted the titles, the intentions of those who approved the law and the conceptual horizons such legislation reveal, law as a source brings both possibilities and problems.

Lombard law also embodies this dual challenge of problems and possibilities. Between 653 and 755, Lombard kings issued a number of codifications [and amendments] of the law. ${ }^{9}$ The question that is immediately begged, of course, is whether such enactments reflected "the " reality at the time of codification. Clearly the prism between the legal texts as we have them now and reality at the point of promulgation is problematic, even were we to accept at face value the fundamental veracity of the texts. ${ }^{10}$ This is an issue that is particularly apposite for the Edictum Rothari (ER). ${ }^{11}$ The prologue tells us that custom is set down but also that "he" (in this case the king himself, Rothari) has reviewed, amended and updated specific clauses. It will be for us to consider this aspect in detail below. ${ }^{12}$

Historiographical responses to Lombard law appear to muddy the waters further. Older discussions of Lombard law were predicated on assumptions of not only their German origin but also their alleged barbarism. ${ }^{13}$ Thus, for the usually phlegmatic Thomas Hodgkin (1831-1913), an entirely scathing overview of Lombard law appeared to be a natural impulse, as we see here:

And so the Lombard invaders, like children, repeat the lessons which they have learned from their forefathers of the forest and try to fit in[to] their barbarous law terms ...the stately but terribly misused language of Latium. Throughout Roman ideas, Roman rights, the very existence of a Roman population are not so much menaced or invaded as calmly ignored. The Code of Rothari, promulgated on the sacred soil of Italy, in a land which had once witnessed the promulgation of the Code, the Institutes and the Digest of Justinian, is like the black tent of the Bedouin pitched amid the colonnades of some stately Syrian temple, whose ruined glories touch no responsive chord in the soul of the swart barbarian. ${ }^{14}$

8 Indeed, the pitfalls are emphasised in significant works; see Davies and Fouracre, Property and Power, 1-3; Rio, Legal Practice, 1-5 with reference to formulae.

9 In terms of titles, Rothari's Edictum has 388 titles; Grimoald added nine; Liutprand 153 titles on fifteen separate occasions; Ratchis fifteen; and Aistulf nine titles.

10 For discussion of the applicability of the $E R$ to conditions in 643 and the manuscript footprint of Lombard law, see Leggi dei Longobardi, ed. Azzara and Gasparri, xxvii-xxx and xlviii-li respectively. One is on firmer ground with Liutprand's law, which, in providing amendment and extension of the law, refers to both current issues and conditions at the point of promulgation.

11 Wormald, Kings and kingship, 598-599; Wickham, Early Medieval Italy, 36-39 and 69-70; Wormald, Lex Scripta; Fischer Drew, Laws of the Salian Franks, 26-27.

12 "We have perceived it necessary to improve and to reaffirm the present law, amending all earlier laws by adding that which is lacking and eliminating that which is superfluous " (necessariam esse prospeximus presentem corregere legem, quae priores omnes renovet et emended, et quod deest adiciat, et quod superfluum est abscidat). Leggi dei Longobardi, ed. Azzara and Gasparri, 13-14, trans. Fischer Drew, Lombard Laws, 39. See Everett's amended translation, Everett, Literacy in Lombard Italy, 164.

13 See the useful precis in Davies and Fouracre, Settlement of Disputes, 2-3.

14 Hodgkin, Italy and her Invaders, 238. Even more positive Anglophone commentators at this time, such as Charles Kingsley (1819-1875) in his lecture series The Roman and the Teuton, opined that the "code « was one of the best ways to study the Lombards since »one may gain some notion of that primeval liberty and self-government, common at first to all«: Kingsley, Roman and Teuton. Everett discusses the Italian work on uncovering the "real sources for Lombard law. See Everett, Literacy in Lombard Italy, 164-167 and n. 3, which furnishes full bibliographical references. 
Subsequent work by historians, however, has recognised that the Laws comprise in toto an invaluable normative source for both the Lombard kingdom and Italian society in the seventh and eighth centuries. ${ }^{15}$ The corpus of Lombard law has been used by historians to address a variety of historical issues. Commentators have, for instance, concentrated upon and considered the witness that the laws comprise for both the intentions of centripetal authority and the ability of that authority to rule, control and shape the socio-economic reality on the ground. In other words, what might be considered possible, reasonable and enforceable and, by implication, what could not. ${ }^{16}$

One may take the view that normative materials dwell upon the mundane and the theoretical. ${ }^{17}$ Yet whilst the analysis of law is not a simple golden key that unlocks the mysteries of early medieval societies, it is still an invaluable resource in understanding the conceptual frameworks within which polities operated. ${ }^{18}$ Legal codes set out what is considered acceptable, or at least expectable in any pertinent scenario. Obviously, what is not comprehensible to those who frame and compose the law - or at least foreseeable by them in specific contexts - should be identifiable by an absence. Thus, if one balances these aspects, one may extrapolate and comprehend the mental furniture of both those who formulated the laws and those who authorised and enacted the codification. Identifying clauses in Lombard law that explicitly allow "x" in circumstance "y « provides us with the potential to perceive what was considered possible in spatial terms. We may go further than this. In tackling those provisions that allow, restrain and prevent or prescribe, we may pinpoint three sets of responses. First, concerning allowance, one may identify what is theoretically conceivable, though this does not simply equate to what may have actually happened on the ground; secondly, regarding restraint, we can see what is considered preventable, although again, not necessarily the actual capacity of any given authority to actually stop what is interdicted; and, thirdly, we consider a linked category, deviance, in other words, what happens when matters go awry, how the situation should be re-balanced and how to deal with opposition that may arise. Theoretically, at least in the interstitial spaces between all these responses, we may find "a" reality or at least a possible meaningful impression of that society.

15 The key editions of the laws may be found in Leges Langobardorum, ed. Blühme; Leggi dei Longobardi, ed. Azzara and Gasparri, trans. Fischer Drew, Lombard Laws. For Gasparri »le leggi longobarde...costituiscono un mezzo per entrare nei meccanismi sociali, economici e culturale dell'eta longobarda... «.ix-x. That said, Gasparri also contends that doubt remains about the historicity of the Edictum as we currently have it. He says, "una legislazione tutta orientate sul passato e priva de riferimento alla societa presente" and "fossero almeno parzialmente obsolete gia al momento dela loro promulgazione«, $\mathrm{x}$-xi.

16 Everett, Literacy in Lombard Italy; Ausenda et al., Langobards; Albertoni, Law and the peasant, 417-445; Sutherland, Idea of revenge. Everett's discussion, for instance, concentrates on the evidence for literacy and literate practices rather than the operation of the kingdom - although his discussion on the immediate circumstances of the issue of the Edictum is very useful.

17 Fischer Drew suggests that law tackles »the unusual rather than the usual condition...«: Fischer Drew, Lombard Laws, 22. Davies and Fouracre held that "political and social structures are best appreciated not through the study of laws and other normative texts, but through charters«: Davies and Fouracre, Property and Power, 1.

18 Faulkner, Law and Authority, 1-5 is a useful discussion. Whilst he observes that the leges barbarorum "are among the richest of all sources of early medieval history" their potential value has "always proved very difficult indeed". Rio is perhaps a little more cautious in that she observes that "historians no longer take [law codes] as a straightforward reflection of society, but they still convey the value systems deployed «; see Rio, Legal Practice. To access the broader debate on the value of law as a historical source, see Fossier, Sources de l'histoire économique and Brunner, Deutsche Rechtgeschichte. 
In our subsequent discussion of the issues raised by a close analysis of the legal titles in the Edictum Rothari and the laws of Liutprand, Ratchis and Aistulf we shall first consider the range of regulations on different forms of movement, namely how the law, in theory, sought to allow, restrain and control movement within both the "public " sphere and the "private" worlds of individuals. Subsequently, we shall broaden the field of enquiry to analyse the spatial theatre in Lombard history before, thirdly, we consider the specific evidence for the crossing of liminal frontiers. Subsequently, wider and broader conclusions, in particular, the implications for the transformation of the Roman world debate, may be drawn. We shall first, however, consider the specific regulations that pertain to movement and mobility.

\section{Allowance, Restraint and Deviance: Impulses and Responses in Lombard Law}

One does not have to scratch far below the surface to see reflected in Lombard law, an apparently dynamic and often mobile society which undertakes forms of quotidian movement naturally. We should, however, at this point be clear about the working definitions of »movement « and "mobility« used in this item. Whilst they are frequently used as synonyms, they may also be defined within narrow and broad contexts. In simple terms, movement may be defined as a physical act of moving. Narrower aspects associated with movement, for instance will relate to relatively banal and short-range activities that in medieval law codes relate to specific actions that may either be permitted or interdicted. "Mobility « may then be defined as the ability to move or be moved freely and easily. In wider contexts it may relate to the principle which allows, or at least does not restrain the theoretical allowance to undertake movement that is more than local or even regional - including the crossing of political frontiers. Further, in setting out a legal framework that permits or allows such movement but also delimits and restricts it, we may be able to identify the boundaries between what might be called the public sphere and the private sphere. In other words, where the implied competence of the "public" authority to control and protect existed and where such competence ended.

Mobility in Lombard law is addressed in implicit terms. Thus there are capitula that deal with both freemen and slaves who are found "in someone else's courtyard " (in curte alterius $)^{19}$ and those that punish freemen or slaves breaking the peace in "another « district, the clear implication being that this is not their own area, and thus constitutes some form of movement. ${ }^{20}$ Activities on the road attract a whole slew of prohibitive titles that include

19 See Leggi dei Longobardi, ER 32 and 33, ed. Azzara and Gasparri, 22-25, trans. Fischer Drew, Lombard Laws, 58-59. The difficulty here appears not to be the simple unauthorised and alien presence of the individual freeman or slave but the temporal framework, i.e. at night, because, as the $E R$ indicates, »it is not consistent with reason that a man should silently or secretly (silentium aut absconse) enter someone else's courtyard at night." Intent would then appear to be the key element here. In Burgundian law, the Liber Constitutionum or Lex Gundobadi also identifies the courtyard as a specific locus of crime. See title 92, which relates to women whose hair has been cut off in their own courtyard. Also of interest here are those provisions which intend to protect vineyards, i.e. title 103. See Leges Burgundionum, ed. Salis, 111 and 114-115, transl. Fischer Drew, Burgundian Code, 82 and 86-87. In Frankish Law, in particular the Lex Salica Karolina, breaking into property rather than being present without fault is the prime concern, e.g. the breaking into the enclosure of a mill (clusam) attracts a separate fine in addition to anything that may be stolen; see Lex Salica, ed. Eckhardt, 222, trans. Fischer Drew, Laws of the Salian Franks, 214-215.

20 Leggi dei Longobardi, ER 39 and 40, ed. Azzara and Gasparri, 24-25, trans. Fischer Drew, Lombard Laws, 60. 
throwing someone from his horse, not extinguishing fires beside the road, allowing freemen to move wherever they like, and even the expulsion of lepers from their "own « district. ${ }^{21}$ We should also mention the two specific capitula which deal with the "magistros Commacini" (master builders of Como) which hints at both the continuance of economic specialisation and employed mobility beyond Como itself. ${ }^{22}$

Both the differences and the similarities between the regulation of different types of movement and, in particular, how they relate to the nature of the persons and places in question, reveal not only the hierarchical impulses in the law code but also the variances in treatment of individuals in spatial responses. Already from the very brief selection of clauses above, it is evident that, in the details of punitive address, Lombard law is hierarchically determined by status. In relation to those lurking in courtyards at night, a freeman may provide compensation of 80 solidi for himself, whereas a slave may be remitted (by his or her Lord) by the payment of 40 solidi, although if either offers resistance they may be killed with impunity. ${ }^{23}$ Not all slaves, however, were encompassed in the same categories in the $E R$. The Edictum Rothari provides three terms for the dependent. First, household slaves (servus ministerialis); secondly, servus massarii, who may be termed tenant slaves; and, thirdly, field slaves or the servus rusticus. Titles 130,132 and 134 in the ER provide an explicit hierarchical pyramid of value. ${ }^{24}$ Household slaves are valued at 50 solidi (although a minor or subordinate is valued at 25 solidi); tenant slaves at 20 , and a field slave is allocated 16 solidi and so on. ${ }^{25}$

21 Leggi dei Longobardi, ER 30, 148, 176 and 177, ed. Azzara and Gasparri, 22-23, 44-45,54-55, trans. Fischer Drew, Lombard Laws, 58, 76, 83-84. Using Everett's division of the $E R$, title 30 pertains to crimes against private individuals; 148 to "damage to property«; and 176 and 177 pertain to laws on succession. Here Everett follows Azzara; see Everett, Literacy in Lombard Italy, 167 and, Leggi dei Longobardi, ed. Azzara and Gasparri, xxviii-xxix. Waylaying or pillaging on the road is directly forbidden in the Pactus Legis Salicae (14 and 21), as is »blocking the road«; see Pactus Legis Salicae, 14 and 21, ed. Eckhardt, 64-69 and 120-121, trans. Fischer Drew, Laws of the Salian Franks, 79 and 94-95. Likewise, in the Lex Burgundionum, title 27 prohibits the blocking of either the "public road" or a "country lane«. For this, see Leges Burgundionum, ed. Salis, 64-65, transl. Fischer Drew, Burgundian Code, 42. The recognition of leprosy triggers expulsion from the civitas or from the leper's own house (the clause pertains to income). For leprosy, see Miller and Smith-Savage, Medieval leprosy.

22 Leggi dei Longobardi, ER 144 and 145, ed. Azzara and Gasparri, 42-45, trans. Fischer Drew, Lombard Laws, 75. For the Magistri, see Leggi dei Longobardi, 119. 58 and 59, ed. Azzara and Gasparri. See also Moschetti, Primordi esegetici. Whilst there is no explicit indication that the "magistri comacini« are peripatetic, the import of the clauses would suggest that their activities were not restricted to Como alone. One may adduce, however, that a certain Rodpertu »magistrum comacinu" was active in Tuscania in 739. See Monneret de Villard, L'organizzazione industriale, 45 .

23 Leggi dei Longobardi, ER 32 and 33, ed. Azzara and Gasparri, 22-25, trans. Fischer Drew, Lombard Laws, 58-59. Consider titles 37 and 38 re: those freemen and slaves who break the peace in a district where the king is present, or simply titles 39 and 40, where the peace is broken in another district.

24 De servo ministeriale occiso/ On killing household slaves; De servo massario occiso/On killing tenant slaves; De servo rusticanum qui sub massario est/On the killing of a field slave subordinate to the tenant slave: Leggi dei Longobardi, ed. Azzara and Gasparri, 38-41, trans. Fischer Drew, Lombard Laws, 72-73. For discussion, see Fischer Drew, Lombard Laws, 30.

25 By way of relative comparison, we find values adumbrated for aldii (half-free) at 60 solidi (ER 129); ox ploughmen at 20 solidi (ER 133); master swine-herders at 50 solidi (ER 135); cattle-herders, goatherds, oxherds all at 20 solidi. If one computes the value globally provided by the litany of unpleasant injuries set out between $E R 48$ and 73 , one may attain a considerable corporeal value, dependent, however, on the personal status of the individual concerned. 
The form of unfreedom delineated in the law is one tethered to unfreedom associated with the tenure of land occupation rather than as a result of slave raiding and trading. ${ }^{26}$ Accordingly, the responses in law to spatial issues are also mediated through a hierarchical pyramid of application, and, as we shall see, this has a direct impact on movement and mobility. In this sense, with regard to allowance, the $E R$ is explicit that freemen (and thus by implication not those who are aldii i.e. the half-free or slaves) are allowed to move and should in theory be left unmolested. This clause is set out below:

De homine libero ut liceat eum migrare

Si quis liber homo, potestatem habeat intra dominium regni nostri cum fara sua megrare ubi voluerit, sic tamen si ei a rege data fuerit licentia...

Concerning freemen who are allowed to move

Any freeman together with his family [fara] has the right to go where-ever he wishes within our kingdom provided that this privilege has been given to him by the king. ${ }^{27}$

Here it is noteworthy that the theoretical allowance to move has been abrogated by the king as a licentia. At first sight it appears that the provision is merely one of theoretical allowance, but it is made clear that movement can also be interdicted by regnal authority and/or action. ${ }^{28}$ In practice, however, one must wonder how feasible it would have been to enforce the "privilege" or even to return those who had not acquired any explicit permission to move. Secondly, the hierarchical approach to movement is demonstrated by the reference to freemen (homine libero) alone. Whilst the regulation is indicative of "a " perceptual view, the difficulties of enforcement would suggest that the provision was only honoured in the breach. ${ }^{29}$

26 This is something that becomes relevant for the ninth century, in the south of Italy in particular. There is some anecdotal evidence for this in the northeast of Italy in the seventh century; see Paul the Deacon, Historia Langobardorum 4, ed. Waitz, 37. On ninth-century slavery, see the account of Bernard Monachus. On eighthcentury slave raids, see Paul the Deacon's account in the $H L$ of Avar raids and subsequently Slavic incursions into Friuli in the eighth century. See Rio, Slavery after Rome.

27 Leggi dei Longobardi, ER 177, ed. Azzara and Gasparri, 54-55, trans. Fischer Drew, Lombard Laws, 83-84. Whilst not referring to this particular title directly, Pazienza notes that the »capitoli dell'Editto...sembrerebbe sancire almeno teoricamente il totale controllo regio sui movimento della populazione». Clearly, as Pazienza suggests, the reality differed. See Pazienza, Mobilita interna, 97-99.

28 On this clause and its broader context, see Fabbro, Warfare and the Making, 175-176. The caveat to the allowance in the clause is: „Et si aliquas res ei dux aut quicumque liber homo donavit et cum eo noluerit permanere el cum heredes ipsius : res ad donatorem vel heredes eius revertantur (If a duke or any other freedman gives him some property and the recipient does not wish to remain with him or his heirs, the property shall revert to the donor or his heirs). Leggi dei Longobardi, ed. Azzara and Gasparri, 54-55, trans. Fischer Drew, Lombard Laws, 83-84. By contrast, in the Pactus Legis Salicae (45) movement into another village to reside was not directly governed by regal allowance but determined by those who lived in the new location: Pactus Legis Salicae, 45, ed. Eckhardt, 172-176, trans. Fischer Drew, Laws of the Salian Franks, 109-110. Further, it is interesting that those provisions that relate to "those who refuse to come to court « do not delineate exceptions based on logistical difficulties in travelling. See Pactus Legis Salicae, 1 and 56 ed. Eckhardt, 18-20 and 210-214, trans. Fischer Drew, Laws of the Salian Franks, 65 and 119.

29 See below, however, for discussion of subsequent attempts to restrict the movement of foreigners. 
On this level of movement, unfettered mobility across and into the kingdom was not circumscribed for the free. The treatment of those described as "waregang" or "foreigners " was, however, also illustrative of a broadly permissive approach.$^{30}$ This is what the clause says:

\begin{abstract}
De Waregang
Omnes waregang qui de exteras fines in regni nostri finibus advenerint seque sub scuto potestatis nostrae subdederint legibus nostris Langobardorum vivere debeant, nisi si aliam legem ad pietatem nostram meruerint. Si filius legetimus habuerint heredes eorum existant sicut et filii Langobardorum; si filius legitimus non habuerint non sit illis potestas absque iussionem regis res suas cuicumque thingare aut per quolibet titulo alienare.
\end{abstract}

\title{
On Foreigners
}

All foreigners who come from outside our frontiers into the boundaries of our kingdom and yield to the jurisdiction of our powers ought to live according to the Lombard laws, unless through our grace they have merited another law. If they have legitimate children these heirs shall live just as do the children of the Lombards. If they do not have legitimate children it shall not be in their power to give away any of their property or to alienate it by any means without the king's consent. ${ }^{31}$

There is much of interest here for our purposes. It is evident from a close scrutiny of the details of this passage that we see a variance between the contingent political rhythms that framed the promulgation of the $E R$ and the thinking demonstrated at the core of the titles. Issued in the immediate context of renewed hostilities between the Lombards and Byzantium, the permissive element of the "waregang" title is somewhat intriguing. Indeed the reports of narrative sources do not sketch out the movement of foreigners into the kingdom as quotidian, tolerable or unimportant. ${ }^{32}$ For our specific purposes two elements of the title should be further considered. First, the use of "advenerint " implies an active movement "into " the jurisdiction. Active is significant, as opposed to the passive process (from the perspective of the population), where those in adjacent territories who were formally "waregang" were rendered into subjects by conquest. This would be relevant, for instance, for those who lived in (modern) Liguria, which, during the course of the 640s, was conquered by Rothari. ${ }^{33}$ Later, it also encompasses the Italo-Romans who became subject to Liutprand as a result of his conquests in the Romagna and the Exarchate of Ravenna in the 730s and 740s. The physical

30 See Bruckner, Sprache von Langobarden; Onesti, Vestigia longobarde, 29-30, who uses the definition "straniero in cerca di protezione«; and Leggi dei Longobardi, ed. Azzara and Gasparri, 126. See also, Everett, Literacy in Lombard Italy, 116.

31 Leggi dei Longobardi, ed. Azzara and Gasparri, 106, trans. Fischer Drew, Lombard Laws, 124-125. Certainly, one must argue for Lombard and Roman rather than necessarily Roman v Lombard. Here again the comments of Gasparri are useful. He says: »...l'editto sia stato applicato anche ai Romani ...un idea..che concorda perfettamente co piu recenti studi sui rapporti fra Longobardi e Romani«, Leggi dei Longobardi, ed. Azzara and Gasparri, xi.

32 I.e. war with Byzantium in 643. One might imagine that this was the legal basis for the acceptance of the settlement of Alzeco, a dux of the Bulgarians reported by Paul the Deacon. Conversely, the Saxons are reported to have left Italy "because it was not permitted to them by the Langobards to live according to their own laws «. See Paolo Diacono, 3.6 and 5.29, ed. Capo, 276-277, trans. Foulke, Paul the Deacon, 234 and 298. For discussion of Alzeco and the Bulgars, see Vlaevska, Storia di un problema storiografico.

33 Balzaretti, Dark Age Liguria. See above re: Alzeco. 
expansion of the kingdom then does not explicitly allow adjustment of the terminology used in the law. Yet, secondly, the title provides a flexibility and discretion on the part of the regnal authority so that if "waregang" should »yield to the jurisdiction of our powers " (potestatis nostrae subdederint) they may remain in the kingdom and »live according to the Lombard laws" (legibus nostris langobardorum vivere debeant). It is not axiomatic that Italo-Romans were "waregang" and there are other independent references in the law which seem to support this reading. ${ }^{34}$ Accordingly despite an apparent articulation of clear spatial limits and conceptual boundaries, we should avoid extrapolation that would see jurisdictions and their boundaries as either softened or hardened. ${ }^{35}$ Cross-referencing this title to the opening global intent of the $E R$ set out by Rothari could even allow us to assert that Rothari's asserted motivations in the prologue run against the allowance set out here. ${ }^{36}$

Allowance with reference to internal mobility also appears to be at the centre of concerns with activities that inhibit or prevent movement on the road. In the first place, in $E R 17$ it is indicated that "if one of our men wishes to come to us, let him come in safety and return to his home unharmed" (si quis ex baronibus nostris ad nos voluerit venere, securus veniat, et inlesus ad suos revertatur...). ${ }^{37}$ This clause has theoretically stringent compositional fines which are also attached to the subsequent clauses 26,27 and 28. This section of the $E R$ deals with offences against the movement of individuals and those committed in specific venues. ${ }^{38}$ Activity described as "wegworin" (road-blocking - glossed as orbitaria) that interferes with the free movement of a free woman or a girl attracts the penalty of 900 solidi as compensation; 20 solidi to a freeman in the case of obstruction alone; and, finally, a further 20 solidi in cases where slaves were inhibited. ${ }^{39}$ The common interdicted activity across all three of these titles is simply placing oneself into the path of a third party to prevent their movement,

34 Occupants of the Romagna and the Exarchate are termed >Romans in pertinent titles in the Lombard laws e.g. Liutprand 127.11 and Aistulf 4.

35 On the principle of personality of law, see Peters, Foreword, xiv: "Germanic law was personal not territorial it 'belonged to each member of a people where-ever he or she went."

36 "In unum previdimus volumine conplectendum, quatinus liceat unicuique salva lege et iustitiae quiete vivere et propter opinionem contra inimicus laborare, seque sousque defendere fines" (We wish to have all law collected in one volume, so that everyone may live peacefully under a secure law and with justice, and so that everyone will willingly work against enemies and defend themselves and their territory). Everett, Literacy in Lombard Italy, 164. See also Leggi dei Longobardi, ed. Azzara and Gasparri, 14-15, trans. Fischer Drew, Lombard Laws, 39. Frequent notices in narrative sources, principally Paul the Deacon's $H L$ would also back this interpretation; see, for instance, the notices on Friuli and the Slavs in HL: 6.24 which reveals a less than harmonious connection. Paolo Diacono, 6.24, ed. Capo, 326-329, trans. Foulke, Paul the Deacon, 266-270.

37 Leggi dei Longobardi, ER 17, ed. Azzara and Gasparri, 20-21, trans. Fischer Drew, Lombard Laws, 56. See also, in relation to the »road«, ER 26 road-blocking wegorin: Leggi dei Longobardi, ER 26, ed. Azzara and Gasparri, 22-23, trans. Fischer Drew, Lombard Laws, 57.

38 Crimes against private individuals in Everett's taxonomy. Everett, Literacy in Lombard Italy, 167.

39 Leggi dei Longobardi, ed. Azzara and Gasparri, 22-23, trans. Fischer Drew, Lombard Laws, 57-58. The level of composition does not suggest that enforcement on the "public « road was any more rigorous than infractions of law on "private« property. For »wegworin«, see Bruckner, Sprache von Langobarden, 213 and Onesti, Vestigia longobarde, 130-131. 
with additional penalties applied if injuries should be inflicted (see $E R 26$ and 27). In a following clause, ER 29, which deals with "him who blocks a field or meadow or any enclosure to another man" (si quis messem suam aut pratum seu qualibet clausura vindicanda homini prohibuerit), such activity is allowable only if undertaken in self-defence, adding that one is guilty if »one blocks the road to a man simply walking along " (sicut ille qui hominem sempleciter viam ambolantem antesteterit...). ${ }^{40}$

This explicit reference to fields and meadows hints at the delineation of public and private spheres of spatial use. A number of other clauses also seem to repeat this distinction. The $E R$ allows, for instance, for movement into gardens where no ill intent is involved which is not considered possible for those sneaking into or found in a courtyard after sunset. In this sense a conceptual boundary has been crossed beyond the public environment of the road into the private world of the individual or landholder. The latter is then endowed with the capacity to determine the good or ill intent of the third party. The title indicates that if one is "seeking his own property and does not do any damage he shall not be guilty" (nam si post suam rem ingreditur et damnum non fecerit, non sit culpavlis). ${ }^{41}$ Licit movement here ultimately depends on the intent of the individual but also upon the venue and the time in and at which the episode occurs. At the same time, however, there is no explicit indication that an individual enjoys an elevated level of protection in exterior public spaces. In terms of spatial frameworks, then, there is some ambivalence at work in the Edictum. There is explicit provision, on the one hand, to safeguard the mobility of individuals undertaking (shortrange) activities and journeys; and there is also protection for the movement of individuals and groups across jurisdictional boundaries; but, on the other hand, with both hierarchical impulses in terms of protection of individuals on the roads and elsewhere, an evident set of limitations is apparent.

If there is not a clear-cut set of responses in the clauses that deal with allowance, one may wonder whether the control and restraint of mobility is demonstrated in equally ambivalent terms. Near the commencement of the Edictum, clauses 3 and 4 prohibit two actions. The first forbids anyone from fleeing outside "the province" (provincia) and the second relates to those who proffer "invitations to or introduction of enemies into the province«; both offences merit the penalty of death without composition. They are reproduced here:

3. Si quis foris provinciam fugere tentaverit [On him who attempts to flee outside the province]

Si quis foris provincia fugire timtaverit, morti incurrat periculum et res eius infiscentur.

He who tries to flee outside of the country shall be killed and his property confiscated.

40 Azzara and Gasparri, Leggi dei Longobardi, 22-23; and Fischer Drew, Lombard Laws, 58 Leggi dei Longobardi, ER 29, ed. Azzara and Gasparri, 22-23, trans. Fischer Drew, Lombard Laws, 58.

41 Leggi dei Longobardi, ER 284, ed. Azzara and Gasparri, 86-87, trans. Fischer Drew, Lombard Laws, 109. There does not seem to be the same presumption of guilt at work here as in the first examples. The concern with boundaries, fences and roads may link in with the suspicion of the uninvited in courtyards. 
4. Si quis inimicus intra provinciam invitaverit [On him who invites enemies within the province]

Si quis inimicus intra provincia invitaverit aut introduxerit, animae suae incurrat periculum et res eius infiscentur.

He who invites or introduces enemies into the land shall be killed and his property confiscated. ${ }^{42}$

Both of these titles are associated with offences against public authority. Emplaced in close proximity to clauses that deal with those who seek the death of the king and to those who assist spies, the rigorous penalties in the clauses are designed to deter those who would choose to challenge the kings in Pavia. ${ }^{43}$ At the same time, both clauses are silent as to the mechanisms of enforcement but, in theory, at least, we might assume that "local « institutional governance (as set out in its fullest expression in the later laws of Liutprand) could be mobilised to restrain those who might flee. ${ }^{44}$ Whilst silent as to effective enforcement, both clauses also imply a finite spatial extent of the kingdom that can be equated with the use of the word "provincia" where this is essentially coterminous with the Lombard kingdom and where "outside« is "anywhere else«. This is deceptive in that the term "provincia" is left undefined in terms of jurisdiction. It might be tempting then, as we saw with the "waregang" clause, to see this inexactitude as a product of the unfixed extent of the kingdom itself. ${ }^{45}$ If, however, we use a narrower definition of "provincia " to connote that area associated with a Lombard $d u x$, we may identify a congruence that connects territories, jurisdictions and borders with conceptual frameworks. Further anecdotal evidence can be found in the $H L$ of Paul the Deacon both generally and specifically with his catalogue of Italian provinces in book 2 of the $H L$, but is also present in his frequent references to specific areas. ${ }^{46}$ Further, in practical terms,

42 Leggi dei Longobardi, ed. Azzara and Gasparri, 114. See also Gasparri, Regno Longobardo in Italia; Bognetti, Santa Maria Foris, 446 n. 164. For comparison in terms of treatment of the malefactor, see Alamannic law title 24: »if anyone invites a foreign nation into the province" (de homine qui gentem extraneam infra provinciam invitaverit): Leges Alamannorum, ed. Lehmann, 84-85, trans. Rivers, Laws of the Alamans, 74.

43 Leggi dei Longobardi, ed. Azzara and Gasparri, 16-17, trans. Fischer Drew, Lombard Laws, 53. Both titles 3 and 4 fall into the section of the Edictum that deals with what might be termed »crimes against public authority«. The implication here is that the offence is one against the public authority in the public sphere.

44 It is interesting that the second clause, if we are to believe Paul the Deacon's $H L$, was a tenet that was breached by Lombard kings themselves - see the invitation of Grimoald (662-671) to the Avars to enter Friuli in the late 660s and nullify the activities of the $d u x$ Lupus: Paolo Diacono, 5.17-20, ed. Capo, 268-273, trans. Foulke, Paul the Deacon, 227-229. For discussion re: Lupus, see Gasparri, Duchi Longobardi, 67-68 and Heath, Narrative Worlds, 217-218.

45 See Secord, Three Worlds Met, 6-11, which sets outs a typology for borders, i.e. »linear boundaries of political demarcation; nonlinear divisions between cultures or barriers; and, border zones or zones of interaction «, in other words zones of separation and zones of interaction. More generally, see Berend, Medievalists and the notion, 5572 and Abulafia and Berend, Medieval Frontiers.

46 Paolo Diacono, 2.14-24, ed. Capo, 94-105, trans. Foulke, Paul the Deacon, 71-79. 
Lombard Italy demonstrates the administrative footprint of Late Roman Italy with its patchwork of dukes and gastalds based in urban centres with discrete and delineated zones of authority. The key geopolitical division in the peninsula, however, that between the Lombards and Byzantium, also fostered a congruent crystallisation of boundaries, concepts and peoples. ${ }^{47}$

\section{The Spatial Theatre in Lombard History}

Up to this point, an analysis of specific titles, principally in the Edictum Rothari, with regard to movement and mobility in Lombard society has been undertaken. Whilst the clauses discussed deal with allowing mobility and restraining illicit movement, they deal specifically with the situation on the ground in the Lombard kingdom. It will, however, also be useful to consider how this operated in wider and broader contexts in what may be termed the spatial theatre of the Lombards. Mobility and movement are one of many pertinent impulses that affect the treatment of Lombard history in Italy.$^{48}$ As we noted above, a paradox of immobility versus mobility is a function of the mixed witness of narrative materials which concentrate on shorter contingent political rhythms. It is often the case, - our main narrative source Paul the Deacon's $H L$ being no exception - that such narratives dwell upon the exceptional rather than the mundane. One may cite Paul's account of his distant relative's escape from Avar slavery courtesy of a friendly wolf as indicative of this sort of response. ${ }^{49}$

Negative appraisals of the Lombard impact on Italy have remained persistent, obscuring in some respects the subtleties of the situations on the ground. If we turn to Latouche again for one emblematic example, his view was that the "Lombard invasion brought disorder as well as poverty to the peninsula «. ${ }^{50}$ For Latouche, the sixth century was an era that was a "muddled spineless Merovingian world «. ${ }^{11}$ Pithy (but mostly incorrect) obiter dicta aside, however, recent work in a variety of historiographical contexts has cut across the grand narratives of the Early Medieval past as perceived by historians writing after the publication of Henri Pirenne's Mahomet et Charlemagne. ${ }^{22}$ There are numerous examples in this

47 One should, nevertheless, remain cautious about the operation of borders in the Early Middle Ages. Sharper borders predicated upon antagonistic geopolitical impulses do not necessarily equate to clear demarcations on the ground. One does wonder whether the Italian situation allowed for greater ease in establishing and upholding perimeters of polities. I thank Dr Gantner for discussion on this point.

48 General surveys include: La Rocca, Italy; Wickham, Early Medieval Italy; Christie, Lombards; Cammarosano and Gasparri, Langobardia; Jarnut, Storia dei Longobardi; and Ausenda et al., Langobards.

49 Paolo Diacono, 4.37, ed. Capo, 218-219, trans. Foulke, Paul the Deacon, 185.

50 Latouche, Western Economy, 119. In this he echoed his mentor Pirenne, who observed that »they [i.e. the Lombards] overran the population, took its land and reduced it to the condition of a vanquished enemy«: Pirenne, Mohammed and Charlemagne, 70. Such responses, of course, have a very long provenance. Gregory the Great's eschatological impulses were often deployed when referring to the Lombards to correspondents.

51 Latouche, Western Economy, 120. One may find rather more positive appraisals of this period and the sixth/ seventh centuries in the essays in Gnasso et al., Long Seventh Century; Esders et al., East and West; Fischer and Wood (eds.), Western Perspectives; Esders et al., Merovingian Kingdoms; and Hodges and Bowden, Sixth Century. And see now Effros and Moreira, Oxford Handbook.

52 Pirenne, Mahomet et Charlemagne. On Pirenne, see Wood, Modern Origins, 224-229. Also useful, Esders and Hen, Introduction. See also Hodges and Whitehouse, Mohammed, Charlemagne; Delogu, Reading Pirenne again; and, Effros, Enduring attraction. 
respect, but two will suffice here to set the scene. Fouracre's recent work, for instance, on the provision of lighting materials for ecclesiastical sites, and what he usefully terms the "moral economy", provides one helpful example of the management of resources beyond a simply local environment. As he indicates, »the expense of materials needed to fuel the lights put the means to provide them beyond the reach of most people. ${ }^{53}$ What interests us here in this context, however, is the plausibility of supply to satisfy demand, and in this respect, the provision of olive oil for lamps in the northern monasteries of Francia was one corollary of the demise of the Lombard kingdom in $774 .{ }^{54}$ But here one finds the enduring paradox of socio-economic frameworks that are not appropriately refined, in that whilst the supply of oil was facilitated across a considerable distance, the production of goods can be seen as a function of a closed economy dependent upon the labour of those restricted in terms of service and freedom. ${ }^{55}$ Contact, movement and mobility need not, however, be restricted to comment on the transport of specialised or even luxury goods across long distances. A second example of work which cuts across the grand narratives of this period, deals with contacts between the Lombards and Avars, who were neighbours to the northeast of the Italian peninsula..$^{56}$ Csánad Bálint's important work, The Avars, Byzantium and Italy sets out and identifies, inter alia, the landscapes of transmission of goods. So far as trade is concerned, his model separates economic transactions pursuant to a hierarchical model predicated upon geographical proximity - i.e. from local to »international.$^{57}$ Clearly functioning trade contacts can be exemplified by all these categories, dependent upon the nature of the goods and their origins. For Bálint, however, whilst there is evidence of Avar export of horses to Italy, "Byzantine and Italian jewellery items, luxury goods, pottery and coins [only] occur sporadically and in low numbers in Avar lands. ${ }^{58}$ The picture, then, even from two distinct examples, is mixed. It highlights the dangers of an undifferentiated definition of trade and transmission, movement and mobility. What impact does this have for Lombard responses to movement and mobility?

To address this question, one must recognise the tensions between the explicit and the implicit in both narrative and normative sources. From the outset, the scenario that we sketched out above is one that can be demonstrated by a careful analysis of the Lombards both in historical terms and in the legal responses to space and control. In discussing, for instance, the early origins of the Lombards in Germania, and at the start of the Historia Langobardorum, Paul the Deacon (c.735-796) tells us that:

53 Fouracre, Lights, power, 369.

54 Fouracre, Lights, power, 373. See also the essays Fouracre "Framing « and lighting; Story, Lands and lights. Economic aspects of the Frankish conquest of the Lombard kingdom are dealt with in Gasparri, 774, 81-174.

55 See, for instance, the charter of Pistoia of 767 cited by Fouracre (Fouracre, »Framing « and lighting, 307) for the reference to Regesta Chartarum Pistoiensium (which I have been unable to consult directly).

56 There are many examples of contact and conflict between the Avars and the Lombards in Paul the Deacon's $H L$. See, for instance, from book 4 alone, Paolo Diacono, 4.4, 4.12 and 4.37, ed. Capo, 184-185, 192-193 and 210-215, trans. Foulke, Paul the Deacon, 152, 159, (both imply a sstater of conflict) and 179-183.

57 Bálint, Avars, Byzantium and Italy, 179. The four categories are local, regional, inter-regional and international. See also Kardaras, Byzantium and the Avars, 135-155; Pohl, Avars, 220-253; and Daim, Byzantine belts.

58 Bálint, The Avars, Byzantium and Italy, 188. 
from this populous Germania then countless crowds of captives are often led away and sold for gain to the people of the south.

ab hac ergo populosa Germania saepe innumerabiles captivorum turmae abductae meridianis populis pretio distrahuntur. ${ }^{59}$

This idea, the fecundity of northern populations, was one that Paul had borrowed from classical ethnography: a trope that allowed commentators to explain the responses of »barbarians " to their space, an apparent need to find alternative sites to expand and their resistance to control by the creation or imposition of defined boundaries that might be envisaged or policed by settled polities to the south.$^{60}$ Throughout his narrative in book 1 of the $H L$, Paul emphasises the modest nature of the Lombards as a people in terms of population and power. He tracks their uncertain progress from the modern Bardengau (to the south of Hamburg and west of the Elbe) to the borders of Italy in 568/569. ${ }^{61}$ Whilst the historicity of Lombard movement in this period need not detain us, his telescoped account of roughly 400 years amply demonstrates the possibility of movement in the four centuries after the first attestation of the Lombards in classical sources. The picture he provides alters once the Lombards have reached the borders of Italy, which was roughly four centuries after the events that the passage above describes. Here, over the following 200 years or so, they ruled a regnum with a core based on the Po plains, comprising most [but not all] of northern and central Italy. This is the point at which the production and codification of law becomes relevant.

As we have already noted with an analysis of the $E R$, geopolitical alterations do not necessarily map across to socio-cultural or economic adjustments. In terms of broader movements of people across Eurasia in the early Middle Ages, the migrations of the Lombards were part of the transformative processes at work on the Roman world, where one theoretically over-arching structure at the level of the empire was replaced by the installation of locally focused and regional regimes. ${ }^{62}$ As is well known, these geopolitical changes do not cohere with socio-economic change propelled by variant rhythms. Such adjustments mask the kaleidoscope of socio-economic, religious and cultural zones, contact regions and communities that linked and divided the Mediterranean world and beyond. In this sense, the spatial theatre in which the Lombards operated once they had settled in Italy was not a »closed« system, nor was it one that demonstrated a uniform cultural conformity. ${ }^{63}$ The complicated

59 Paolo Diacono, 1.1, ed. Capo, 12-13, trans. Foulke, Paul the Deacon, 2 (with adjustments by the author); Paul the Deacon, Historia Langobardorum, ed. Waitz, 48. See the useful discussion of James and the concept of »barbarism« in James, Europe's Barbarians 200-600, 1-15. See also Jones, Image of the barbarian.

60 James, Europe's Barbarians, 21-30. Strabo was of the view that "it is a common characteristic of all the peoples in this part of the world [i.e. Germania beyond the Rhine] that they migrate with ease, because of the meagreness of

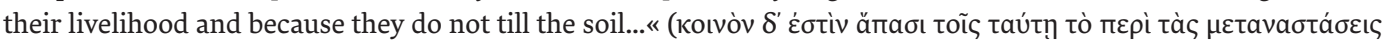

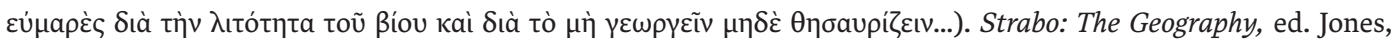
156-157. On Strabo, see Almagor, Who is a barbarian?, 42-55.

61 For discussion of this period, see Cingolani, Storie dei Longobardi and, Rotili, I Longobardi.

62 Local aspects of societies are dealt with in Cooper and Wood, Social Control; Zeller et al., Neighbours and Strangers, and the essays in Rousseau and Raithel, Companion to Late Antiquity. Locally focused studies include Viso, Reino y las sociedades locales; Hummer, Politics and Power; and, Innes, State and Society, to name only three. This could be characterised as the replacement of an «imperial« space in which Italy acted as the centre to the creation of multipolar post-imperial spaces. The insecure and fissiparous tapestry of Italy in the period 568-640 renders this post-imperial space complicated and contingent. See Van Nuffelen, Historiography and Space.

63 Fouracre, Cultural conformity. See also Fouracre, Space, culture and kingdoms. 
and often chaotic political conditions in Italy between c.568 and c.640 demonstrates the connectivity of the Lombards within the wider Mediterranean world, but also beyond to the Avars, the Franks and the Barvarians who were neighbours to the east, west and north; their geographical locus linked them into both the Atlantic world and the steppe worlds of the Avars and others. A flexibility to spatial contexts was part of this initial period of settlement in Italy which saw expansion beyond the kingdom's core in the Po valley to Spoleto, Benevento and even attempts to expand into Provence in Gaul. ${ }^{64}$

After the interregnum of 574 to 584 , however, the spatial viewpoint of the Lombard kingdom is increasingly fixed and orientated around the Po valley in the north. Whilst the description of the nineteen provinces of Italy by Paul the Deacon does not associate specific provinces with the Lombards, the transit of his narrative demonstrates an increasing effort to stabilise the spatial and liminal framework of the kingdom. In terms of spatial perspective, the residence of the early kings moves from Verona to Milan to Pavia, but it is the Po valley that retains a centrality in terms of governance and law. ${ }^{65}$ Paul the Deacon provides a notice that Authari (584-590) identified a column adjacent to Reggio di Calabria. This was the point where, the king declared, »the territories of the Langobards will be up to this place" (usque hic erunt Langobardorum fines). ${ }^{66}$ Yet, for all practical intents, both Spoleto in the centre of the peninsula and Benevento in the south remained politically exterior to the kingdom throughout the long seventh century. The promulgation of the $E R$, which follows on from this period, as we have seen above, marks a specific point, a snapshot of responses and impulses before the relatively unfixed parameters of the Lombard kingdom are increasingly ossified. The period between the death of Rothari and the accession of Liutprand (i.e. 651-712), during which no significant territorial adjustments were undertaken, was the backdrop to this crystallisation of spatial responses, which will be considered below in respect of Lombard frontiers.

\section{The Limits of the Frontier}

Although Rothari and the Lombards had recommenced territorial expansion in earnest from the 640 s, after a period of consolidation post-interregnum of 574-584, the geopolitical framework of the peninsula remains stable for the next 75 years or so. The $E R$ itself, as we saw above, both condones and restricts movement and mobility. In the final half-century of the kingdom, however, Lombard law reveals new attempts to maintain and control its own spatial framework, to determine and manage licit mobility, and to stop illicit movement.

Part of this impulse to control movement and solidify frontiers was predicated upon events in the early eighth century. The Lombard hegemony in the peninsula orchestrated by Liutprand had been undermined by both the emergence of the papacy as an independent protagonist and by Frankish interventions into Italy. This is demonstrated by two key provisions in the laws of Ratchis (744-749 and $756-757) .{ }^{67}$ First, Ratchis attempted to prevent the movement of representatives:

64 For the spatial turn, see Lefebvre, Production of Space; de Certeau, Practice of Everyday Life; Rohkrämer and Schulz, Space, place and identities; and Withers, Place and the spatial turn.

65 For Pavia as a "site of power«, see Bougard, Public power and authority, 44-45.

66 Paolo Diacono, 3.32, ed. Capo, 168-169, trans. Foulke, Paul the Deacon, 145-146.

67 These have been analysed in detail by Walter Pohl; see Pohl, Frontiers in Lombard Italy. 
Si quis iudex aut quiscumque homo missum suum diripere presumpserit Roma, Ravenna, Spoleti, Benevento, Francia, Baioaria, Alamannia, Ritias aut in Avaria sine iussione regis animae suae incurrat periculum et res eius infiscentur.

If a judge or any other man without the king's permission presumes to send his representative to Rome, Ravenna, Spoleto, Benevento, Francia, Bavaria, Alamannia, Raetia or to the land of the Avars, he shall lose his life and his property shall be confiscated.. ${ }^{68}$

And the second emphasised the importance of guarding and maintaining the boundaries

ut inimici nostri et gentes nostre non possint per eas sculcas mittere aut fugacis exientes suscipere, sed nullus homo sine signo aut epistola regis exire possit

in order that neither our enemies nor our people can send spies through them or allow fugitives to go out and in order that no man can enter without a letter sealed by the king ${ }^{69}$

It is noteworthy, in the first place, that Ratchis explicitly sets out those areas that are considered to be external to the Lombards, in theory at least. All of the places highlighted can be considered to be exterior to the kingdom proper. The presence of Spoleto, Benevento and Ravenna in the list is intriguing. They had all formed part of the inclusive and expansionist dimensions of Liutprand's and (subsequently) Aistulf's (749-756) kingdom and were part of the Lombard political space in the eighth century. In this sense, they were not exterior in a spatial sense. ${ }^{70}$ This clause, no doubt prompted by contingent political rhythms pertinent in the 750s, pinpoints the awareness of the conceptual boundaries of the kingdom but does not seem to take account of the developments earlier in the century. The second relevant clause attempts to create fixed control of the borders and aimed to constrain movement across, through and into the kingdom. We should be cautious in accepting at face value the detailed provisions in a subsequent title of Ratchis which set out the procedure for compliance. ${ }^{71}$ There is still a conundrum at work here which needs explanation. One solution would be to see the clauses above as part of a continuum of responses and evidence for an increasing crystallisation of the Lombard »spatial« zone. With this reading, the titles become evidence for a conscious formulation of a Lombard spatial zone which is defined and expressed by its opposition to adjacent polities. Such expression in border or contact zones such as Friuli may always have been sharper due to the proximity of exterior communities, identities and polities.

68 Leggi dei Longobardi, ed. Azzara and Gasparri, 268-269, trans. Fischer Drew, Lombard Laws, 221. Pohl, Frontiers in Lombard Italy, 117-121 sets out the immediate geopolitical context of the title.

69 Leggi dei Longobardi, ed. Azzara and Gasparri, 272-273, trans. Fischer Drew, Lombard Laws, 223-224.

70 Indeed, in relation to law, both Spoleto and Benevento used Lombard law issued in the regnum proper. For further detail and discussion of autonomous governance, see Conti, Il Ducato di Spoleto, 171-174 and Zornetta, Italia meridionale longobarda, 32. Waldman reminds us that "Benevento had a much deeper relationship with the Lombard Kingdom than is often assumed, one that actually encouraged the dukes and their people to embrace more firmly their Lombard identity both before and after 774«; see Waldman, Pavia's Twin, 6.

71 Pohl, Frontiers in Lombard Italy, 117-121. 
Finally, let us briefly look at deviance from societal and legal injunctions in this regard. We have already seen in the discussion above that Lombard law attempts to set out a framework of mixed allowance and restraint, albeit rather unbalanced. As we noted, it is often entirely silent about crucial aspects of enforcement. This, in effect, reifies the intangible tension between the two impulses. The reality of this tension between hubris and performance in the laws is sketched out by the witness of provisions that relate to fugitives and runaway slaves that mark the limits of the Lombard kingdom's powers. We find that if slaves flee, re-imposition of physical control and restriction is envisaged. More pertinent, however, is that Liutprand's law provides a period of three months for the lord »to seek him out" (eius eum perquirere). Subsequently Liutprand issued further clarification on his provision in V.88, where the geographical realities on the ground are set out. ${ }^{72}$ Here again, fugitive slaves are tackled - and a specific duration provided for a lord to seek out a fugitive is set out within specific areas. For Benevento and Spoleto the period is three months, for Tuscia two months, and anywhere else in the regnum, one month. These durations set out the view from Pavia, rather than demonstrate a particular difficulty in these areas themselves. ${ }^{73}$ This is also reflected in a remarkable capitula which concerns fugitives, slaves and strangers. The clause issued in Liutprand's additions of 723 marks a distinct shift in both the willingness of Lombard rulers to countenance unfettered movement allied to an organisational impulse that sought to control the situation on the ground throughout the entire regnum. Here Liutprand indicates that:

Si in alia iudiciaria inventus fuerit, tunc deganus aut saltarius, qui in loco est, conprehendere debeat et ad schuldahis suum perducat, et ipse schuldahis eum iudici suo consignet. Et ipse iudex potestatem habeat eum inquirendum, unde ipse est...

If a fugitive or a stranger has been found in another judicial district, then the deganus or the forester [saltarius] in that region ought to take him and lead him to his own schultheis and the schultheis shall consign the fugitive to his judge. The judge shall have the power to enquire of him from what place he comes. ${ }^{74}$

The law sets out in full the consequences of failure to undertake these pertinent enquiries but also provides for a time limit of one month in »these parts « or »for across the mountains that is in parts of Tuscia, it shall be two months ${ }^{75}$ Responses to this sort of deviance from conformity are also addressed in the laws of Ratchis and Aistulf. Both were fundamentally concerned with boundaries and infiltration - a product of the instability of the kingdom at that time as a result of Frankish interventions. Not only did Ratchis ban judges or "any other man" (quiscumque homo) from sending representatives outside the kingdom without permission ${ }^{76}$ but he also sought to regulate and restrict access to the kingdom. Ratchis sets out his thinking directly: 
On protection of the frontiers

Hoc autem statuere previdimus: ut marcas nostras Christo custodiente sic debeat fieri ordinatas et vigilatas, ut inimici nostri et gentes nostre non possint per eas sculcas mittere aut fugacis exientes suscipere, sed nullus homo per eas introire possit sine signo aut epistola regis. Propterea unusquisque iudex per marcas sibi commissas tale stadium et vigilantium ponere debeat et per se et per locopositos et clausarios suos, ut nullus homo sine signo aut epistola regis exire possit.

It is our command, that with the help of Christ, our boundaries will be maintained and guarded in order that neither our enemies nor our people can send spies through them or allow fugitives to go out and in order that no man can enter them without a letter sealed by the king. Every judge should use such care and vigilance with regard to the frontier committed to him both in his own actions as well in those of his local officials and gate wardens that no man can go without a letter sealed by the king. ${ }^{77}$

Ratchis is particularly anxious about "strangers" (peregrini) who "plan to go to Rome». These are to be "diligently" questioned. To underscore this, Ratchis impels the judges in Tuscia in particular to ensure that no one should depart without authorisation. This tone of suspicion of travellers is also echoed in Aistulf's law on broken boundaries issued in $750 .{ }^{78}$ Here is a clear transit in terms of both geographical specificity and performance. As we saw above in the $E R$, borders or zones of contested control are implicitly acknowledged. Later law attempted to create a fixed line of control with detailed mechanisms of restraint using local networks of power to control the situation on the ground and by so doing to create a Lombard space and a non-Lombard space which was to be policed and guarded by mechanisms set out in detail in law. Two final points are worth emphasising. In the first place, clear geographical parameters are enunciated with regard to specific territories (which in some respects is a reflection of the experiences of the Italian peninsula in the early eighth century); and in the second place, in concert with the vigorous "new " kingship of Liutprand and his successors, we see an operative and conscious extension of the horizons of competence and ability of the Lombard kings and kingdom. This manifested in a capillary arrangement which expected local agents of the kings to enforce and maintain control of movement on the ground.

\section{Conclusions}

A comparison between the titles of the $E R$ and the later law of Liutprand, Ratchis and Aistulf is illustrative. It has allowed this article to consider both the specific and narrow witness of Lombard law with respect to movement and mobility but also to seek to place this within the broader landscape of the spatial theatre of the Lombards. Identifying the interpretative balance between movement and mobility on the one hand and restriction and control on the other has also been one of the key concerns of this contribution, and in this respect this is reflected in the tensions evident in the law. Those who provided the framework of law do not supply straightforward responses to the issues highlighted above. However, in the formulation of what is and what is not perceived as enforceable and thus in the actual reified spatial

77 Leggi dei Longobardi, ed. Azzara and Gasparri, 272-273, trans. Fischer Drew, Lombard Laws, 224.

78 Leggi dei Longobardi, ed. Azzara and Gasparri, 282-283, trans. Fischer Drew, Lombard Laws, 229. 
framework, we may detect clear responses to mobility and movement. Layering our analysis into allowance, restraint and deviance also permits us to identify tensions and contradictory impulses in the laws. We have seen that on an uncomplicated basis the laws provided a clear framework that positively allowed movement for certain sections of Lombard society; it incorporated a specific concern to ensure that movement on the road was not restricted or contested, which suggests a concern for specific areas in the public zone, whereas, at the same time, we may identify concerns regarding entry into the private zone of individuals and properties. The apparent absence in the $E R$ of effective mechanisms for control and enforcement should cause us to pause when we consider the effective power of the Lombard kings. We have also seen that there were theoretical limitations to movement and these were associated with those who were unfree. Our difficulties, however, must remain associated with the issues that arise as to the applicability of law and its effective use on the ground. That said, analysis has pinpointed a shift in the perceptual dynamics of Lombard law, which, affected by short-term and contingent political rhythms, narrowed the horizons of the kingdom and sought to police mobility. This is evident in the later laws of Ratchis and Aistulf but not absent within the corpus we have of Liutprand's laws. On the other hand, the Edictum Rothari presents a society open to movement and trade, and one where kings in Pavia could not control fixed borders. Ultimately, attaining an effective balance between security and mobility, between inter-connectivity and migration, proved to be a set of tensions that were irreconcilable for the Lombard kingdom.

\section{Acknowledgements}

My thanks to Clemens Gantner and Edoardo Manarini for their comments on earlier drafts and to the anonymous referees for their apposite and useful insights, which assisted the production of the final version. 


\title{
References
}

\author{
Abbreviations \\ $\mathrm{ER}=$ Edictum Rothari \\ $\mathrm{HL}=$ Historia Langobardorum \\ MGH = Monumenta Germaniae Historica
}

Abulafia, David and Nora Berend (eds.), Medieval Frontiers: Concepts and Practices (Aldershot, 2002).

Albertoni, Giuseppe, Law and the peasant: Rural society and justice in Carolingian Italy, Early Medieval Europe 18 (2010) 417-445.

Almagor, Eran, Who is a barbarian? The barbarians in the ethnological and cultural taxonomies of Strabo, in: Daniela Dueck, Hugh Lindsay and Sarah Pothecary (eds.), Strabo's Cultural Geography: The Making of a Kolossourgia (Cambridge, 2005) 42-55.

Ausenda, Giorgio, Paolo Delogu and Chris Wickham (eds.), Langobards before the Frankish Conquest: An Ethnographic History (Woodbridge, 2009).

Bálint, Csánad, The Avars, Byzantium and Italy: A Study in Chronology and Cultural History (Budapest, 2010).

Balzaretti, Ross, Dark Age Liguria (London, 2013).

Balzaretti, Ross, Julia Barrow and Patricia Skinner (eds.), Italy and Early Medieval Europe: Papers for Chris Wickham (Oxford, 2018).

Barbiera, Irene, Francesco Borri and Annamaria Pazienza (eds.), I Longobardi a Venezia: Scritti per Stefano Gasparri (Turnhout, 2020).

Berend, Nora, Medievalists and the notion of the Frontier, Medieval History Journal 2 (1999) 55-72.

Bognetti, Gian Piero, Santa Maria Foris Portas di Casteseprio (Milan, 1948).

Bougard, François, Public power and authority, in: Cristina La Rocca, Italy in the Early Middle Ages (Oxford, 2002) 34-58.

Brown, Thomas S., 680 (?) and all that: A problematic turning point in the history of early medieval Italy, in: Irene Barbiera, Francesco Borri and Annamaria Pazienza (eds.), I Longobardi a Venezia: Scritti per Stefano Gasparri (Turnhout, 2020) 261-272.

Bruckner, Wilhelm, Die Sprache von Langobarden (Strasbourg, 1895).

Brunner, Heinrich, Deutsche Rechtgeschichte (Leipzig, 1906).

Cammarosano, Paolo and Stefano Gasparri (eds.), Langobardia (Udine, 1990).

Christie, Neil, The Lombards: The Ancient Langobards (Oxford, 1995).

Cingolani, Stefano M., Le Storie dei Longobardi: Dall'origine a Paolo Diacono (Rome, 1995).

Conti, Pier Maria, Il Ducato di Spoleto e la storia istituzionale dei Longobardi (Spoleto, 1982).

Cosentino, Salvatore, Storia dell'Italia Bizantina (VI-XI secolo) (Bologna, 2008).

Cooper, Kate and Jamie Wood (eds.), Social Control in Late Antiquity: The Violence of Small Worlds (Cambridge, 2020).

Daim, Falko, Byzantine belts and Avar birds: Diplomacy, trade and cultural transfer in the eighth century, in: Walter Pohl, Ian Wood and Helmut Reimitz (eds.), The Transformation of Frontiers: From Late Antiquity to the Carolingians (Leiden, 2001) 143-188.

Davies, Wendy and Paul Fouracre (eds.) The Settlement of Disputes in Early Medieval Europe (Cambridge, 1986). 
Davies, Wendy and Paul Fouracre (eds.) Property and Power in the Early Middle Ages (Cambridge, 1995).

de Certeau, Michel, The Practice of Everyday Life (Berkley, 1988).

Delogu, Paolo, L'Editto di Rotari e la società del VII secolo, in: Javier Arce and Paolo Delogu (eds.), Visigoti e Longobardi (Florence, 2001) 329-356.

Delogu, Paolo, Reading Pirenne again, in: Richard Hodges and William Bowden (eds.), The Sixth Century: Production, Distribution and Demand (Leiden, 2003) 15-40.

Effros, Bonnie, The enduring attraction of the Pirenne thesis, Speculum 92 (2017) 184-208.

Effros, Bonnie and Isabel Moreira (eds.), The Oxford Handbook of the Merovingian World (Oxford, 2020).

Esders, Stefan and Yitzhak Hen, Introduction, in: Stefan Esders, Yaniv Fox, Yitzhak Hen and Laury Sarti (eds.), East and West in the Early Middle Ages: The Merovingian Kingdoms in Mediterranean Perspective (Cambridge, 2019) 1-6.

Esders, Stefan, Yaniv Fox, Yitzhak Hen and Laury Sarti (eds.), East and West in the Early Middle Ages: The Merovingian Kingdoms in Mediterranean Perspective (Cambridge, 2019).

Esders, Stefan, Yitzhak Hen and Pia Lucas (eds.), The Merovingian Kingdoms and the Mediterranean World (London, 2019).

Everett, Nicholas, Literacy in Lombard Italy c. 568-774 (Cambridge, 2005).

Fabbro, Edoardo, Warfare and the Making of Early Medieval Italy (568-652) (London, 2020).

Faulkner, Thomas, Law and Authority in the Early Middle Ages: The Frankish Leges in the Carolingian Period (Cambridge, 2016).

Fischer, Andreas and Ian Wood (eds.), Western Perspectives on the Mediterranean: Cultural Transfer in Late Antiquity and the Early Middle Ages 400-80o (London, 2014).

Fossier, Robert, Sources de l'histoire économique et sociale du Moyen Âge occidental (Turnhout, 1999).

Fouracre, Paul, Cultural conformity and social conservatism in early medieval Europe, History Workshop Journal 33 (1992) 152-161.

Fouracre, Paul, Eternal light and earthly needs: Practical aspects of the development of Frankish immunities, in: Paul Fouracre and Wendy Davies (eds.), Property and Power in the Early Middle Ages (Cambridge, 1995).

Fouracre, Paul, Space, culture and kingdoms in early medieval Europe, in: Peter Linehan and Janet L. Nelson (eds.), The Medieval World (London, 2001) 366-380.

Fouracre, Paul (ed.), New Cambridge Medieval History 1: c.500-c.70o (Cambridge, 2005).

Fouracre, Paul, »Framing « and lighting: Another angle on transition, in: Ross Balzaretti, Julia Barrow and Patricia Skinner (eds.), Italy and Early Medieval Europe: Papers for Chris Wickham (Oxford, 2018) 305-314.

Fouracre, Paul, Lights, power and the moral economy of early medieval Europe, Early Medieval Europe 28 (2020) 367-387.

Gasparri, Stefano, I Duchi Longobardi (Rome, 1978).

Gasparri, Stefano, Regno Longobardo in Italia: Struttura e Funzionamento di un stato Altomedievale, in: Stefano Gasparri and Paolo Cammarosano (eds.), Langobardia (Udine, 1990) 237-305.

Gasparri, Stefano (ed.), 774: Ipotesi su una transizione (Turnhout, 2008).

Gelichi, Sauro and Stefano Gasparri (eds.), Venice and its Neighbours from the 8th to the 11th Century: Through Renovation and Continuity (Leiden, 2017).

Gnasso, Alessandro, Emanuele E. Intagliata and Thomas J. MacMaster (eds.), The Long Seventh Century: Continuity and Discontinuity in an Age of Transition (Oxford, 2015). 
Halsall, Guy, The barbarian invasions, in: Paul Fouracre (ed.), New Cambridge Medieval History 1: c.50o-c.70o (Cambridge, 2005) 35-55.

Heath, Christopher, The Narrative Worlds of Paul the Deacon: Between Empires and Identities in Lombard Italy (Amsterdam, 2017).

Hodges, Richard and David Whitehouse, Mohammed, Charlemagne and the Origins of Europe: The Pirenne Thesis in the Light of Archaeology (London, 1983).

Hodges, Richard and William Bowden (eds.), The Sixth Century: Production, Distribution and Demand (Leiden, 2003).

Hodgkin, Thomas, Italy and her Invaders 6 (Oxford, 1895).

Hummer, Hans J., Politics and Power in Early Medieval Europe: Alsace and the Frankish Realm 600-1000 (Cambridge, 2005).

Innes, Matthew, State and Society in the Early Middle Ages: The Middle Rhine Valley 400-1000 (Cambridge, 2000).

James, Edward, Europe's Barbarians 200-600 (Harlow, 2009).

Jarnut, Jorg, Storia dei Longobardi (Milan, 2002).

Jones, William R., The image of the barbarian in medieval Europe, Comparative Studies in Society and History 13 (1971) 376-407.

Kardaras, Georgios, Byzantium and the Avars 6th-9th Centuries: Political, Diplomatic and Cultural Relations (Leiden, 2018).

Kingsley, Charles, The Roman and the Teuton: A Series of Lectures (London, 1891).

La Rocca, Cristina, Italy in the Early Middle Ages (Oxford, 2002).

Lambert, Tom, Law and Order in Anglo-Saxon England (Cambridge, 2017).

Latouche, Robert, The Birth of the Western Economy: Economic Aspects of the Dark Ages (London, 1961).

Lefebvre, Henri, The Production of Space (London, 1991).

Leges Alamannorum, ed. Karl Lehmann, MGH: Leges 5/1: Legum Nationum Germanicarum (Hanover, 1962). English translation: Theodore John Rivers, Laws of the Alamans and Bavarians (Philadelphia, 1977).

Leges Burgundionum, ed. Ludwig Rudolf von Salis, MGH: Leges 1: Legum Nationum Germanicarum Hanover, 1892). English translation: Katherine Fischer Drew, The Burgundian Code (Philadelphia, 1976).

Leges Langobardorum, ed. Friedrich Blühme, MGH Leges 4 (Hanover, 1868).

Le Leggi dei Longobardi: Storia, memoria e diritto di un popolo germanico, ed. Claudio Azzara and Stefano Gasparri (Rome, 2005). English translation: Katherine Fischer Drew, The Lombard Laws (Philadelphia, 1973).

Lex Baiwariorum, ed. Ernst von Schwind, MGH: Leges 5/2: Legum Nationum Germanicarum (Hanover, 1962).

Lex Salica, ed. Karl August Eckhardt, MHG Leges 4/2: Legum Nationum Germanicarum (Hanover, 1969). English translation: Katherine Fischer Drew, The Laws of the Salian Franks (Philadelphia, 1991).

Leyerle, Blake, Mobility and the traces of empire, in: Philip Rousseau (ed.), A Companion to Late Antiquity (Chichester, 2009) 110-123.

Loseby, Simon, The Mediterranean economy, in: Paul Fouracre (ed.), New Cambridge Medieval History 1: c.500-c.700 (Cambridge, 2005) 605-638.

Mango, Cyril and Roger Scott, The Chronicle of Theophanes Confessor: Byzantine and Near Eastern History A.D. 284-813 (Oxford, 1997). 
McCormick, Michael, The Origins of the European Economy: Communications and Commerce 300-900 (Cambridge, 2001).

Miller, Timothy S. and Rachel Smith-Savage, Medieval leprosy reconsidered, International Social Science Review 81 (2006) 16-28.

Monneret de Villard, Ugo, L'organizzazione industriale nell'Italia longobarda durante l'Alto Medioevo, Archivio Storico Lombardo 46 (1919) 1-83.

Moschetti, Guiscardo, Primordi esegetici sulla legislazione longobarda nel sec. IX a Verona secondo il Cod. Vat. Lat. 5359 (Spoleto, 1954)

Onesti, Nicoletta Francovich, Vestigia longobarde in Italia (568-774): Lessica e antroponimia (Rome, 2000).

Pactus Legis Salicae, ed. Karl August Eckhardt, MGH Leges 4/1: Legum Nationum Germanicarum (Hanover, 1962). English Translation: Katherine Fischer Drew, The Laws of the Salian Franks (Philadelphia, 1991).

Paolo Diacono: Storia dei Longobardi, ed. and trans. Lidia Capo (Vicenza, 1992). English translation: William Dudley Foulke, Paul the Deacon: History of the Langobards (Philadelphia, 1907).

Paul the Deacon, Historia Langobardorum, ed. Georg Waitz, MGH Sciptores rerum Langobardicarum et Italicarum (Berlin, 1878) 7-156.

Pazienza, Annamaria, Mobilita interna: Lavoratori e donne in movimento nel Regno longobardo, in: Irene Barbiera, Francesco Borri and Annamaria Pazienza (eds.), I Longobardi a Venezia: Scritti per Stefano Gasparri (Turnhout, 2020) 93-110.

Peters, Edward, Foreword, in: Katherine Fischer Drew (ed.), The Lombard Laws (Philadelphia, 1973) v-xxii.

Pirenne, Henri, Mahomet et Charlemagne (Paris, 1937).

Pirenne, Henri, Mohammed and Charlemagne (London, 1954).

Pohl, Walter, The Avars: A Steppe Empire in Central Europe 567-822 (Ithaca, 2018).

Pohl, Walter, Frontiers in Lombard Italy: The laws of Ratchis and Aistulf, in: Walter Pohl, Ian Wood and Helmut Reimitz (eds.), The Transformation of Frontiers: From Late Antiquity to the Carolingians (Leiden, 2001) 117-142.

Rio, Alice, Legal Practice and the Written Word in the Early Middle Ages (Cambridge, 2009).

Rio, Alice, Slavery after Rome 500-1100 (Oxford, 2017).

La Rocca, Cristina (ed.), Italy in the Early Middle Ages (Oxford, 2002).

Rohkrämer, Thomas and Felix Schulz, Space, place and identities, History Compass 5 (2009) 1338-1349.

Rotili, Marcello, I Longobardi: Migrazioni, etnogenesi, insediamento, in: Giuseppe Roma (ed.), I Longobardi del Sud (Rome, 2010) 1-77.

Rousseau, Philip and Jutta Raithel (eds.), A Companion to Late Antiquity (Chichester, 2009).

Secord, Sarah Davis, Where Three Worlds Met: Sicily in the Early Medieval Mediterranean (Ithaca, 2017).

Story, Joanna, Lands and lights in early medieval Rome, in: Ross Balzaretti, Julia Barrow and Patricia Skinner (eds.), Italy and Early Medieval Europe: Papers for Chris Wickham (Oxford, 2018) 315-338.

Strabo: The Geography, ed. Horace Leonard Jones (London, 1917-1932).

Sutherland, Jon N., The idea of revenge in Lombard society in the eighth and tenth centuries:

The cases of Paul the Deacon and Liudprand of Cremona, Speculum 50 (1975) 391-401.

Van Nuffelen, Peter, Historiography and Space in Late Antiquity (Cambridge, 2019). 
Viso, Iñaki Martín, El reino y las sociedades locales en la Hispania visigoda, in: Irene Barbiera, Francesco Borri and Annamaria Pazienza (eds.), I Longobardi a Venezia: Scritti per Stefano Gasparri (Turnhout, 2020) 273-282.

Vlaevska, Anna, Storia di un problema storiografico: A proposito delle orme (proto)bulgare in Italia tra leggenda e memoria storica, Études Balkaniques 52 (2016) 722-771.

Waldman, Martin, Pavia's Twin: Power and Identity in Early Medieval Benevento (570-899 CE). Unpublished $\mathrm{PhD}$ thesis (Washington, 2017).

West-Harling, Veronica (ed.), Three Empires, Three Cities: Identity, Material Culture and Legitimacy in Venice, Ravenna and Rome, 750-1000 (Turnhout, 2015).

Wickham, Chris, Early Medieval Italy: Central Power and Local Society 400-100o (Ann Arbor, 1981).

Wickham, Chris, Framing the Early Middle Ages (Oxford, 2005).

Withers, Charles, Place and the spatial turn in geography and history, Journal of the History of Ideas 70 (2009) 637-658.

Wood, Ian, The Modern Origins of the Early Middle Ages (Oxford, 2013).

Wormald, Patrick, Kings and kingship, in: Paul Fouracre (ed.), New Cambridge Medieval History 1: c.50o-c.70o (Cambridge, 2005) 571-604.

Wormald, Patrick, Lex scripta and verbum regis: Legislation and Germanic kingship, in: Peter H. Sawyer and Ian N. Wood (eds.), Early Medieval Kingship (Leeds, 1977) 105-138.

Zeller, Bernhard, Charles West, Francesca Tinti, Marco Stoffella, Nicolas Schroeder, Carine van Rhijn, Steffen Patzold, Thomas Kohl, Wendy Davies and Miriam Czock, Neighbours and Strangers: Local Societies in Early Medieval Europe (Manchester, 2020).

Zornetta, Giulia, Italia meridionale longobarda (Rome, 2020). 